\title{
Factorial Validation of Teachers' Self-Efficacy Scale using Pre-Service Teachers: Implications for Teacher Education Curriculum
}

Catherine U. Ene ${ }^{1}$, Christian S. Ugwuanyi ${ }^{1,2}$, Chinedu I.O. Okeke², Boniface G. Nworgu ${ }^{1}$, Agnes O. Okeke ${ }^{1}$, John J. Agah $^{1}$, Basil C. Oguguo ${ }^{1}$, Francis E. Ikeh ${ }^{1}$, Kenneth O. Eze ${ }^{3}$, Felicia C. Ugwu ${ }^{1}$, Oluchi Janehilda Agugoesi ${ }^{1}$, Ekwutosi M. Nnadi ${ }^{3}$, Uche N. Eze ${ }^{4}$, Dominic U. Ngwoke ${ }^{4}$, Uchechukwu H. Ekwueme ${ }^{4}$

${ }^{1}$ Department of Science Education, Faculty of Education, University of Nigeria, Nsukka

${ }^{2}$ School of Education Studies, Faculty of Education, University of the Free State, Bloemfontein, 9300, South Africa

${ }^{3}$ Department of Arts Education, Faculty of Education, University of Nigeria, Nsukka

${ }^{4}$ Department of Educational Foundations, Faculty of Education, University of Nigeria, Nsukka

Correspondence: Agnes O. Okeke, Department of Science Education, Faculty of Education, University of Nigeria, Nsukka.

Received: August 18, 2020

Accepted: October 12, 2020

Online Published: October 14, 2020

doi:10.5430/ijhe.v10n1p113

URL: https://doi.org/10.5430/ijhe.v10n1p113

\begin{abstract}
Teachers' beliefs in their ability to effectively handle the tasks that are related to their professional activity are an issue of concern for pre-service teachers. Many of them have low self-efficacy which can affect their output in future, and this can influence important academic outcomes on learners. The main purpose of this study was to factorially validate teachers' self-efficacy scale (TSES) using pre-service teachers in public colleges of Education in Enugu State. A sample of 218 year three students in the schools of sciences and social sciences was drawn from a population of 2,127 students of public colleges of Education in Enugu State. Simple random sampling technique was used to draw two schools from the five schools in each of the colleges. Accidental sampling was used to draw the participants. The study adapted the teacher self-efficacy scale developed by Ma, Trevethan and Lu (2019). The instrument was construct validated using factor analysis while the internal consistency and stability reliability indices were estimated using Cronbach alpha method and Pearson correlation. The exploratory and confirmatory factors analyses were done using principal component matrix with Varimax rotation, while data model fit was tested using root mean square error of approximation (RMSEA) and confirmatory factor index (CFI). Statistical Package for Social Sciences (SPSS) and Analysis of a Moment Structures (AMOS) software were used to conduct the statistical analysis. The results showed that the scale was found to be valid and reliable and as well demonstrated a good model fit $(\mathrm{RMSEA}=.043, \mathrm{CFI}=.943)$. The study has implication for teacher education training institutions in that the scale can be used as an effective instrument for determining the teaching self-efficacy of the pre-service teachers. Thus, it was recommended that various higher institutions for teacher education should make effective use of TSES in ascertaining the teaching self-efficacy of the pre-service teachers, especially during teaching practice exercises.
\end{abstract}

Keywords: confirmatory factor analysis, exploratory factor analysis, pre-service teachers, self-efficacy scale

\section{Introduction}

Education is an instrument that launches any nation into science and technology with the consequential hope of improved living conditions, human advancement and national development. Education helps a man to function effectively in any environment through the development of physical, mental, social and technological aspects of man (Federal Republic of Nigeria [FRN], 2013). Education is the most important instrument for changes in the society's intellectual and social outlook (FRN, 2004). Therefore, for a Nation to achieve a sustainable development, there is need to improve the quality of its education.

Teachers are important agents through whom the quality of education can be improved. A teacher is a person who must have been trained pedagogically to be capable of assisting the learners acquire knowledge, attitudes and skills (Okeke et al., 2019). Njoku et al. (2017) said that a teacher is a person who imparts knowledge, information, skills, values, attitudes or whatever to a person or group of persons assumed relatively inexperienced or unskilled in a manner that is morally acceptable and pedagogically efficient. Teacher education involves all the policies and procedures which have been designed to enable pre-service teachers to imbibe the knowledge, attitude, behavior and 
skills which will enable them to perform their task effectively in the classrooms, schools and their wider society. Offorma (2016) observed that teacher education empowers persons who will provide education to the young and inexperienced members of the society to become functional members of the society. The teacher is a key player in the success of individual student in the classroom (Colson et al., 2017).

A pre-service teacher is one who is in a teacher education programme to acquire the knowledge and skills that will help him impart knowledge to learners. Pre-service teachers are those who are in a teacher education programme to pursue teaching credentials in public schools or private sectors domestically or internationally (Dejene et al., 2018). The pre-service teacher is gradually introduced into the teaching role by a mentor or a cooperating teacher. Dejene et al. further noted that the pre-service teacher begins as an observer and finishes the pre-service teaching experience as a competent professional. They are student teachers who undergo training in an institution of learning. They are also called practicing teachers. Gavora (2011) believed that overt teacher behavior in the classroom has an invisible complement-teacher belief. Gavora (2011) opined that self-efficacy is a significant teacher characteristic within the area of beliefs and assumptions.

Bandura (1997) defined self-efficacy as a belief in one's ability to perform a certain task. Zuya et al. (2016) defined self-efficacy as the conviction one has about their capabilities to perform certain tasks effectively. Zuya et al. further found that high self-efficacy pre-service teachers tend to be more motivated to learn than the low self-efficacy pre-service teachers. Although Hascher and Wepf in Colson et al. (2017) stated that pre-service teachers' positive emotions are associated with teaching. Hascher and Hagenauer in Colson et al. (2017) observed that anxiety, nervousness and worry are also prevalent among the pre-service teachers. Reyel et al. (2001) stated that feeling connected and having a sense of self-efficacy for the teaching responsibilities is imperative for pre-service teachers.

This work is anchored on Bandura's theory which states that one's ways of thinking and feeling are determine by self-efficacy beliefs. Kendra (2019) observed that people with a strong sense of self-efficacy view challenging problems as tasks to be mastered. Ugwuanyi et al. (2020) found that self-efficacy determined to a large extent one's ability to perform in certain task. Stressful conditions which often result in teacher burnout are associated with profession of teaching (Prillel-Tensky et al., 2016). This explains why it is necessary to develop a scale for measuring pre-service teachers' self-efficacy.

Pendergast et al. (2011) studied pre-service student-teacher self-efficacy beliefs using 179 pre-service and found that during the final semester of their teacher training programme, the pre-service teachers rated themselves with a lower level of teacher self-efficacy than they had done previously. Zuya et al. (2016) researched to determine the confidence levels of pre-service teachers' self-efficacy in mathematics and mathematics teaching found that pre-service mathematics teachers had above average confidence levels in both mathematics self-efficacy (MSE) and mathematics teaching self-efficacy (MTSE). Self-efficacy scale is a tool/instrument which can be used to measure one's self-efficacy. Self-efficacy is a psychological construct that its items are measured by the use of psychological test/scale. However, Souza et al. (2017) noted that measurement instruments that assess psychological constructs are available but many of these instruments have not been properly validated. Validation involves the collection and analysis of data for assessing the accuracy of an instrument used in collecting data. Researchers have always expressed the need for thorough evaluation of measurement properties of instruments. According to Zaki (2017), information provided by any clinical instrument should be subjected to validation based on judgement and decision-making process (Zaki, 2017). Quality of results of measurement also depends on the quality of instruments used to gather the information.

The instrument must offer accurate, valid and interpretable data for accurate information on outcome of learning to be gathered. A good instrument must be reliable and valid. Reliability is the degree of consistency of an instrument in producing reproducible results over time. According to Souza et al. (2017), reliability is the ability of an instrument to produce consistent measurements at different times under the same conditions. Nworgu (2015) defined reliability as a degree of consistency or stability which the test exhibits. Validity, on the other hand, is a quality of an instrument which ensures that the instrument measures what it purports to measure. Construct validity measures the extent to which the test measures a psychological construct which it is meant to measure (Nworgu, 2015).

This paper focused on factorial validation of pre-service teachers' self-efficacy scale. Souza et al. (2017) noted that factorial validation determines the structural construct validity of instruments by assessing the correlation in a big number of variables defining factors. For proper evaluation of psychological constructs, important information regarding the psychometric properties of the items to be included in the final form of the scale for measuring pre-service teachers' self-efficacy should be determined. Both EFA and CFA were carried out in this study. 
Literature has revealed that teachers' actions are influenced by their beliefs and assumptions about the school, teaching and student. Some pre-service teachers in colleges of education find themselves in the programme because they could not gain admission into the main programme of their interest in the universities and polytechnics. They are therefore, forced to study any available course. Again, considering the unemployment problem in the country, some of them feel that there is more job opportunity in the teaching profession. Literature has also revealed that most scholars focused on pre-service teachers' performance and implementation of the pre-service teaching programme without considering the state of the pre-service teachers that are admitted into the teaching programme. Therefore, to the best knowledge of the researchers, very few validated instruments are available for assessing pre-service teachers' self-efficacy. Thus, the researchers determined the exploratory factor analysis as well as the confirmatory factor analysis of the Ma, Trevethan and Lu's Pre-service teachers' self-efficacy scale (TSES) using pre-service teachers in colleges of education in Enugu State.

\section{Methods}

\subsection{Participants}

A sample of 218 year 3 students in the schools of sciences and social sciences formed the participants for the study. The sample was drawn from the population of all pre-service teachers in the Colleges of Education who are pursuing the National Certificate in Education (NCE). There are 2,127 NCE students in the two public colleges of Education in Enugu State in the 2018/2019 academic session. The Colleges of Education are Federal College of Education, (FCE), Eha-Amufu and Enugu State College of Education (Technical), (ESCET), Enugu. Simple random sampling was used to draw 2 schools from the 5 schools in each of the colleges. Accidental sampling was used to draw a sample of 218 year 3 students in the schools of sciences and social sciences. Year 3 students were used because it is assumed that year 3 students have gone through the NCE programme including micro teaching and the macro teaching (practical teaching) and are in a position to express their self-efficacy in teaching.

\subsection{Measure}

An instrument known as Teachers Self-efficacy Scale developed by Ma, Trevethan and Lu (2019) was adapted and validated for the study. The only difference was in the number of response options. The items of TSES were sub-divided into three sections based on Ma, Trevethan and Lu, (2019) levels of pre-service self-efficacy namely, efficacy for instructional strategies, efficacy for management of student behavior and efficacy for engagement of students. The instrument is intended to assess respondents' sense of efficacy in a teaching environment. The full 24-item teacher self-efficacy scale was used. The original version of the TSES was translated into Chinese but was later translated back to English with some changes which Ma, Trevethan and Lu (2019) made concerning the instructions, items and response options. The items underwent series of translations and back translations until all the discrepancies were resolved and the final 24 items of the TSES were arrived at.

\subsection{Ethical Consideration}

The ethical approval for the conduct of this study was granted by the University of Nigeria committee on research ethics. The participants were served with informed consent forms to fill and sign before the commencement of the data collection.

\subsection{Data Collection Procedure}

In order for the researchers to gain entry into the sampled colleges of education, permission letters were sought from the provost of the colleges used. After obtaining the permission letters, the researchers arranged for the data collection timetable which was followed throughout the data collection period. The researchers with the help of some research assistants were able to administer the copies of the instrument within the stipulated period of data collection. After that, the completed copies of the instrument were sorted out and arranged for analysis.

\subsection{Data Analysis}

Data collected were analyzed using exploratory and confirmatory factor analysis using SPSS and IBM SPSS AMOS respectively. Principal component analysis with varimax rotation in SPSS was used to carry out EFA. CFA was carried out using IBM SPSS AMOS. The SEM approach was done using analysis of moment structures (AMOS) version 16.0. Confirmatory factor index (CFI), Chi-square goodness of fit test, and root mean square error of approximation (RMSEA) were used to test the model fit for the data. This analytic method has been used by Ugwuanyi and Okeke (2020a, 2020b), 


\section{Results}

Table 1. Kaiser-Meyer-Olkin (KMO) and Bartlett's Test for the Adequacy of the sample for the EFA of TSES

\begin{tabular}{|c|c|c|}
\hline \multicolumn{2}{|c|}{ Kaiser-Meyer-Olkin Measure of Sampling Adequacy. } & .881 \\
\hline & Approx. Chi-Square & 3454.981 \\
\hline \multirow[t]{2}{*}{ Bartlett's Test of Sphericity } & Df & 610 \\
\hline & Sig. & .000 \\
\hline
\end{tabular}

Table 1 shows that the KMO measure for the exploratory factor analysis of the items of TSES is 0.881 which shows an adequate sample size for the factor analysis. Table 1 also showed that the Bartlett's test of sphericity is significant a $p=0.000$ which is less than 0.05 . This means that the correlation matrix for the TSES is not an identity matrix.

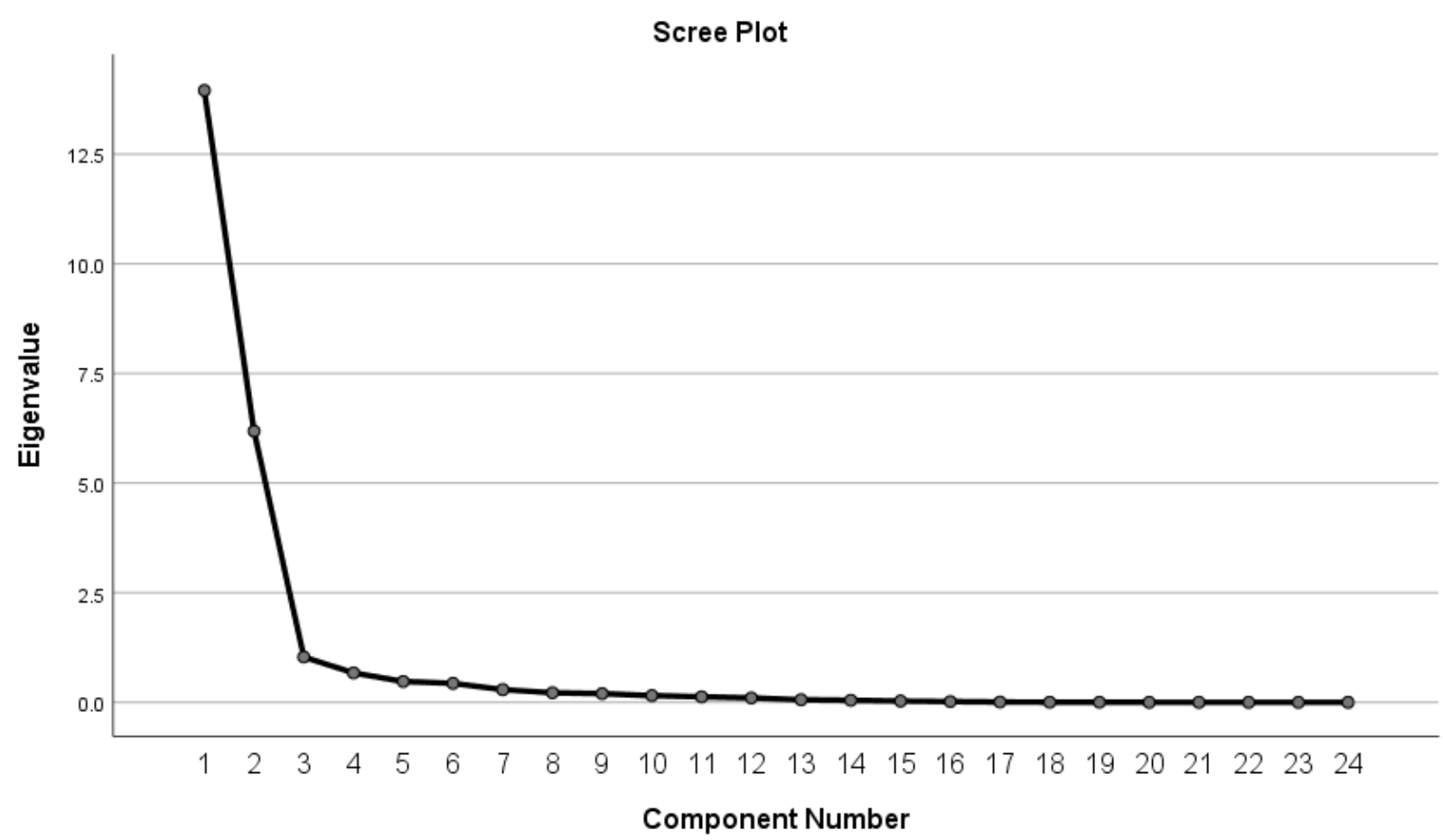

Figure 1. Scree plot for the exploratory factor analysis of the TSES items

Table 2. Extraction and rotation sum of squares loadings that associated with the Factors

\begin{tabular}{lllllll}
\hline \multirow{2}{*}{ Component } & \multicolumn{2}{l}{ Extraction Sums of Squared Loadings } & \multicolumn{3}{l}{ Rotation Sums of Squared Loadings } \\
& Total & \% of Variance & Cumulative \% & Total & \% of Variance & Cumulative \% \\
\hline 1 & 13.954 & 58.141 & 58.141 & 13.636 & 56.817 & 56.817 \\
2 & 6.185 & 25.771 & 83.911 & 6.438 & 26.827 & 83.644 \\
3 & 1.034 & 4.308 & 88.219 & 1.098 & 4.575 & 88.219 \\
\hline
\end{tabular}

Table 2 shows that the eigenvalues from 1.098 to 13.636 are associated with the rotated sums of square loadings of the three subscales of TSES with the highest eigenvalue explaining $56.817 \%$ from the total variance, while the lowest eigenvalue explained $4.575 \%$ from the total variance. The results further showed that the extraction eigenvalues did not vary much from those of the rotation eigenvalues. This means that the items of TSES loaded strongly on the three factors at the extraction level. 
Table 3. Rotated Component Matrix for the TSES Items

\begin{tabular}{|c|c|c|c|}
\hline \multirow[b]{2}{*}{ Item statement } & \multicolumn{3}{|c|}{ Component } \\
\hline & 1 & 2 & 3 \\
\hline 1. Ability to help the most difficult students & .966 & & \\
\hline 2. Assisting students to be able to think critically & .956 & & \\
\hline 3. Managing classroom disruptive behavior & .944 & & \\
\hline 4. Reinforcing students who have low interest in schoolwork through motivation & .944 & & \\
\hline 5. Setting clear expectations of students' behavior & .943 & & \\
\hline 6. Developing students' self-confidence in schoolwork & .942 & & \\
\hline 7. Ability to attend to students' difficult questions & .941 & & \\
\hline 8. Ability to keep routine activities running freely & .925 & & \\
\hline 9. Ability to assist the students to have value for their learning & & .924 & \\
\hline 10. Ability to understand the level of students' comprehension of what is being taught & & .915 & \\
\hline 11. Being able to set good questions for students & & .913 & \\
\hline 12. Helping to develop sense of creativity in the students & & .865 & \\
\hline 13. Helping the students abide by the classroom rules & & .823 & \\
\hline $\begin{array}{l}\text { 14. Assisting the failing students to improve in their understanding of a student lesson } \\
\text { contents }\end{array}$ & & .805 & \\
\hline 15. Ability to control disruptive or noisy students & & .787 & \\
\hline 16. Being able to set classroom management system for the students & & .761 & \\
\hline 17. Ability to modify your lessons to favor students of different abilities & & & .975 \\
\hline 18. Ability to employ different assessment strategies & & & .953 \\
\hline 19. Being able to keep a few problem students from running an entire lesson & & & .934 \\
\hline 20. Ability to provide an alternative explanation for the students at the face of confusion & & & .930 \\
\hline $\begin{array}{l}\text { 21. Ability to render assistance to families to ensure that their children perform well in } \\
\text { school }\end{array}$ & & & .909 \\
\hline 22. Ability to implement alternative strategies in your classroom & & & .906 \\
\hline 23. Ability to provide appropriate challenging situation for very brilliant students & & & .830 \\
\hline 24. Ability to manage students' defiant behavior & & & .526 \\
\hline
\end{tabular}

Extraction Method: Principal Component Analysis.

Rotation Method: Varimax with Kaiser Normalization.

a. Rotation converged in 4 iterations.

Table 3 revealed that three subscales of TSES were extracted using principal component analysis with varimax rotation. A cut of correlation coefficient of 0.45 was used as the criterion for the factor loadings for the items. Out of the 24items of TSES, 8 items each loaded above 0.45 factor loading in the three subscales. The factor loadings showed that the items correlated very highly among themselves for each of the subscales of the TSES.

Table 4. Reliability of the Subscales of TSES

\begin{tabular}{lll}
\hline Subscale & Cronbach Alpha $(\alpha)$ & Test-retest \\
\hline Engagement of students & .816 & .881 \\
Instructional strategies & .898 & .867 \\
Management of students' behavior & .761 & .901 \\
TSES & $\mathbf{. 8 9 3}$ & $\mathbf{. 8 9 8}$ \\
\hline
\end{tabular}


Table 4 shows that engagement of students' subscale of TSES had a reliability index of 0.816 , instructional strategies subscale had a reliability index of 0.898 , while management of students' behavior subscale had a reliability index of 0.761 . The overall reliability index of TSES is 0.893 . Table 4 also shows that each of the subscales of TSES had good temporal stability indices which ranged from 0.881 to 0.9201 with an overall temporal stability index of 0.898 . This showed that TSES is a stable instrument for measuring teachers' sense of efficacy.

Table 5. Model Fit Indices for the TSES Data

\begin{tabular}{llllll}
\hline Model & RMSEA & CFI & PCFI & $\chi^{2}$ & $\mathrm{p}$ \\
\hline Default model & .043 & .943 & .967 & 210.78 & .000
\end{tabular}

RMSEA = Root Mean Square Error of Approximation, CFI= Confirmatory Factor Index, PCFI = Parsimony Confirmatory Factor Index, $\chi^{2}=$ Chi-Square, $p=$ Probability value

Table 5 shows that the default $R M S E A=.043 ; C F I=.943, P C F I=.967, \chi 2(215)=210.78, p=.000$ for the goodness-of-fit indices of the TSES data. This showed that the TSES data had an adequate model fit since the $C F I$ value was higher than .90 and the RMSEA value was less than .05 . Besides, the standardized regression weights for factor loadings for the three-factor model were statistically significant with the regression coefficients ranging between 0.44 and 1.01 as shown in Figure 2.

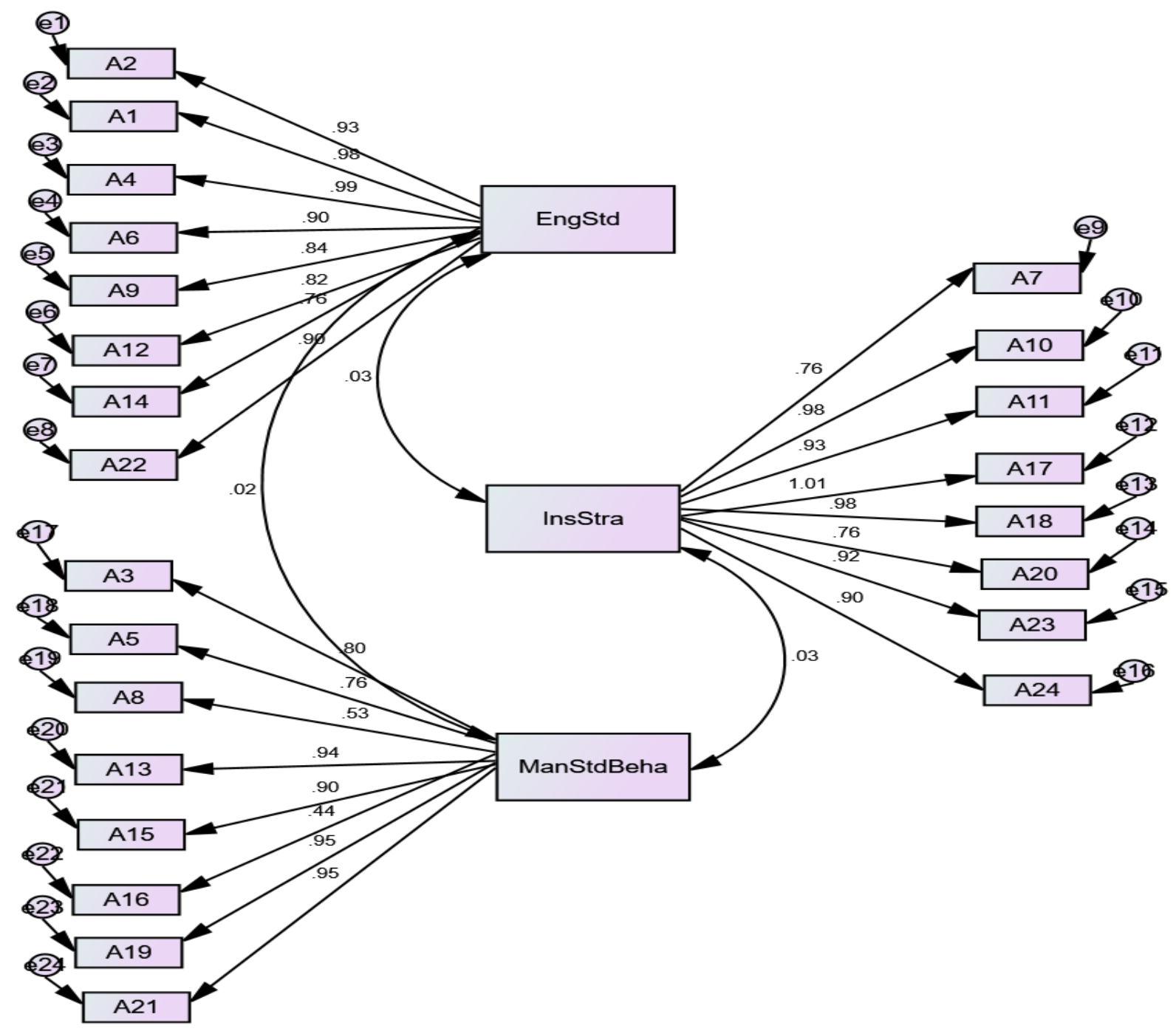

Figure 2 . Path diagram tor the saturated estimates

EngStd = Engagement of students, InsStra = Instructional Strategies, ManStdBeha $=$ Management of students' behavior 


\section{Discussion of Findings}

This study adopted and validated the TSES Developed by Ma, Trevethen and Lu (2019). Ma, Trevethan and Lu adapted, translated and factorially validated the original version of the TSES which was written in Chinese language. The finding revealed that the 24-item teacher-efficacy scale is valid and reliable for measuring pre-service teacher-efficacy. The pre-service teacher needs to be confident in himself to be motivated to accomplish the task of teaching. Therefore, the pre-service teacher should have a conviction that he/she will succeed in a given task. An individual's self-efficacy plays a major role in how goals, tasks and challenges are approached. Kendra (2019) noted that people with a strong sense of self-efficacy view challenging problems as tasks to be mastered and as a result develop deeper interest in activities. This explains why it is important that a valid and reliable scale for measuring pre-service teachers' self-efficacy should be developed to help ascertain pre-service teachers' self-efficacy. When this scale is used, it will enable the pre-service teachers to be motivated and have confidence in themselves to be able to manage the stress associated with the teaching profession. According to Prillel-Tensky et al. (2016), the teaching profession is stressful and often results in teacher burnout.

The teacher self-efficacy scale will help the pre-service teachers understand their level of self-efficacy and even strive harder to develop a higher level of self -efficacy. Zuya et al. (2016) noted that there is need for people's conviction about their capabilities to carry out certain tasks suitably and effectively. This can only be determined by using a valid and reliable scale like the teacher self-efficacy scale. Zuya et al. further noted that the self-efficacy of the pre-service mathematics teachers and that of the mathematics teachers are significantly related. Factor analysis conducted on the TSES also confirmed the three sub-scales namely engagement of students, instructional strategies and management of students' behavior. These sub-scales were initially identified by Ma, Trevethan and Lu (2019). Pendergast et al. (2011) also identified three sub-scales of the pre-service teacher self-efficacy as efficacy for instructional strategies, efficacy for classroom management and efficacy for student engagement. Pendergast et al. however discovered that during the final semester of their teachers' training programme, the pre-service teachers rated themselves with a lower level of teacher self-efficacy than they had done previously. Also, there was little difference noticed between the three sub-scales with the mean for each of the sub-scales declining during the final semester of their teacher training. The study also discovered that the items of the TSES correlated very well meaning that the items are very closely related to pre-service teacher self-efficacy. The instrument which was found to be valid in China is also valid in Enugu State, Nigeria and can be used to determine the self-efficacy of pre-service students. The finding of this study implicates teacher education training institutions, in that the scale can be used as an effective instrument for determining the teaching self-efficacy of the pre-service teachers.

\subsection{Conclusion}

The issue of pre-service teacher self-efficacy should be given priority attention if Nigeria's quest for national development in the $21^{\text {st }}$ century would be actualized. It is important to note that indices of development begin with the development of human beings who will later develop other facets of the society. The pre-service teachers in colleges of education are trained to teach at the foundation schools for children's development and thus examining their teaching self-efficacy both at training and during service becomes eminent. This is because the quality of education offered to students/pupils depends on the quality of the teachers. Understanding the self-efficacy beliefs of pre-service teachers who impart knowledge, information, values and skills to students is therefore important.

\subsection{Implications of the Findings}

1. This finding implicates teacher education curriculum of every teacher training institution in Nigeria, implying that the scale can be used as an effective instrument for determining the teaching self-efficacy of the pre-service teachers.

2. The scale will help pre-service teachers understand their level of self-efficacy at entry and on exit in the teaching programme which will help them achieve more during the real business of teaching and learning.

3. Teacher educators are directly involved in inculcating all the policies and procedures which have been designed to enable pre-service teachers imbibe knowledge, attitude and skills of teaching. Therefore, they need to be equipped with an instrument with which they can measure the level of self-efficacy of their students and know how to help them achieve better.

\subsection{Recommendations}

1. Various higher institutions for teacher education should make effective use of TSES in ascertaining the teaching self-efficacy of the pre-service teachers, especially during teaching practice exercises.

2. The TSES can be administered on the pre-service teachers on entry into the pre-service training and during their exit year in the pre-service programme to determine their levels of self-efficacy at entry and on exit in the 
programme. This will reveal to the pre-service teachers and the teacher educators the level of self-efficacy of pre-service teachers at entry and on exit in the programme.

\section{References}

Bandura, A. (1997). Self-efficacy: The exercise of control. New York: Freeman.

Colson, T., Sparks, K., Berridge, G., Frimming, R., \& Willis, C. (2017). Pre-service teachers and self-efficacy: A study in contrast. Discourse and Communication for Sustainable Education, 8(2), 66-76. https://doi.org/10.1515/dcse-2017-0016

Dejene, W., Bishaw, A., \& Dagnew, A. (2018). Pre-service teachers' approaches to learning approach preferences. https://doi.org/10.1080/2331186X.2018.1502396

Federal Republic of Nigeria. (2013). National Policy on Education. Lagos: NERDC Press. Federal Republic of Nigeria (2014:8). National Policy on Education. Lagos: NERDC Press.

Gavora, P. (2011). Measuring the self-efficacy of In-service Teachers in Slovakia. Orbis Scholae, 5(2), 79-94. https://doi.org/10.14712/23363177.2018.102

Kendra, C. (2019). Self-efficacy and why believing in yourself matters. Theories of Personality Psychology. Studio Firma/Stocksy United, Verywell mind. https://www.verywellmind.com/what-is-self-efficacy-2795954

Ma, K., Trevethan, R., \& Lu, S. (2019). Measuring teacher sense of efficacy: Insights and recommendations concerning scale design and data analysis from research with pre-service and inservice teachers in China. Frontiers of Education in China, 14(4), 612-686. https://doi.org/10.1007/s11516-019-0029-1

Njoku, U. M., Amadi, G. U., \& Igbokwe, C. N. (2017). Teachers' classroom discipline and sustainable development in public secondary schools in Imo State. International Journal of Studies in Education, 15(13), 319-330.

Nwagu, E. K. N. (2005). Method of research design. In D. N. Ezeh (Ed). What to write and how to write: A step-by-step Guide to Educational Research Proposal and Report. Enugu: Pearls and Gold Publishers

Nworgu, B. G. (2015). Educational Measurement and Evaluation: Theory and Practice. Nsukka: University Trust Publishers.

Offorma, G. C. (2016). The purpose of Teacher Education. In Ivowi, U. M. O. (ed). Teacher Education in Nigeria. Lagos: Formast Educational Services Ltd.

Okeke, F. C., Enyi, C., Agu, P. U., Chigbu, B. C., \& Nwankwo, P. P. (2019). Teachers' perceptions on the ethical standard of instructional supervision required of secondary school Principals in Onitsha Education Zone in Anambra State. Review of Education: Institute of Education Journal, 31(1), 247-265.

Pendergast, D., Garvis, S., \& Keogh, J. (2011). Pre-service student teacher self-efficacy beliefs. An insight into the making of Teachers, 36(12), 46-58. https://doi.org/10.14221/ajte.2011v36n12.6

Prillel-Tensky, L., Neff, M., \& Bessel, A. (2016). Teacher stress. What is, why it's important, how it can be alleviated. Theory into Practice, 55(2), 104-111. https://doi.org/10.1080/00405841.2016.1148986

Ryel, R., Bernsausen, D., \& Van-Tassel, F. (2001). Advocating Resiliency through wellness. Paper presented at the 2001 Association of Teacher Educators annual meeting. New Orleans: CA.

Souza, A. C., Allexandre, N. M. C., \& Guirardello, E. D. (2017). Psychometric properties in instruments evaluation of reliability and validity. Epidermial Serve Saude Brasilia, 26(3). https://doi.org/10.5123/S1679-49742017000300022

Ugwuanyi, C. S., Okeke, C. I. O., \& Asomugha, C. G., (2020). Prediction of learners' mathematics performance by their emotional intelligence, self-esteem, and self-efficacy. Cypriot Journal of Educational Science, 15(3), 492-501. http://doi.org/10.18844/cjes.v\%vi\%i.4916

Ugwuanyi, C. S. \& Okeke, C. I. O. (2020a). Determinants of University students' interest in Science, Technology, Engineering and Mathematics Education in Nigeria: A case of a structural equation modelling. International Journal of Mechanical and Production Engineering Research and Development, 10(3), 6209-6218. http://doi.org/10.24247/ijmperdjun2020590

Ugwuanyi, C. S., \& Okeke, C. I. O. (2020b). Psychometric Properties of the Pain Self-Efficacy Questionnaire Using Nigerian University Students with Chronic Pain. Indian Journal of Public Health Research \& Development, 
$11(6)$, 1517-1522.

Retrieved

from https://scholar.google.com/scholar?hl=en\&as_sdt=0\%2C5\&q=Ugwuanyi $\% 2 \mathrm{C}+\mathrm{C} . \mathrm{S} . \% 2 \mathrm{C}+\% 26+\mathrm{Okeke} \% 2 \mathrm{C}+\mathrm{C} . \mathrm{I}$ $.0 .+\% 282020 \% 29 .+$ Psychometric+Properties+of +the+Pain+Self-Efficacy+Questionnaire+Using+Nigerian+Uni versity+Students+with+Chronic+Pain.+Indian+Journal+of+Public+Health+Research+\%26+Development $\% 2 \mathrm{C}+$ $11+\% 286 \& b \operatorname{tnG}=22 / 08 / 2020$

Zaki, R. (2017). Validation of instrument measuring continuous variable in medicine. https://doi.org/10.5772/66151

Zuya, H. E., Kwalat, S. K., \& Attah, B. G. (2016). Pre-service teachers' mathematics self-efficacy. Journal of Education Practice, 7(14), 93-98.

\section{Copyrights}

Copyright for this article is retained by the author(s), with first publication rights granted to the journal.

This is an open-access article distributed under the terms and conditions of the Creative Commons Attribution license (http://creativecommons.org/licenses/by/4.0/). 